\title{
Biblioteksbygninger som kulturarv
}

\author{
Af Nan Dahlkild
}

Når talen i almindelighed falder på emnet biblioteker og kulturarv, er det typisk bibliotekernes indhold, der tænkes på: Samlingerne af inkunabler, sjældne bøger, forfatteres manuskripter, formidlingen af de litterære klassikere m.m. De færreste tænker på rammerne om opbevaringen og formidlingen $\mathrm{i}$ form af selve biblioteksbygningerne som en del af kulturarven. Her deler bibliotekerne sandsynligvis skæbne med arkiv- og museumsbygninger. Også her er det først og fremmest indholdet, der er defineret som kulturarv.

Rammerne i form af bygninger og indretning har dog deres egen historiske forankring. De er i mange tilfælde karakteristiske udtryk for forskellige perioders kulturpolitiske forestillinger og arkitektoniske retninger. De afspejler samtidens opfattelse af det kulturelle indholds betydning og konkrete formidling. Dermed bliver bygningerne med deres forskelligartede kvaliteter i sig selv en del af kulturarven.

Denne indfaldsvinkel svarer til de senere års bredere interesse for bolig- og bymiljøer som sociale og historiske helheder, hvor der ikke blot lægges vægt på det historisk eller æstetisk unikke, men hvor også den hverdagsmæssige brug og betydning har fået karakter af kulturarv.

Omvendt var offentlighedens tidligste interesse for bevaring og fredning inspireret af romantikkens forkærlighed for enestående landskaber og for de ældste historiske monumenter. Det er typisk bygninger med stor historisk, kunstnerisk eller arkitektonisk værdi, der er først og bedst beskrevet af store oversigtsværker som f.eks. Laurids de Thurahs Den danske Vitruvius fra 1746-49 eller senere på baggrund af grundig registrering og forskning af et værk som Danmarks Kirker, som påbegyndtes i 1933. I det 20. århundrede har bevaringsinteressen i takt med industrialiseringen bredt sig til også at omfatte ældre borgerlige k $\varnothing$ bstadshuse eller karakteristiske landbrugsbygninger, ofte med vægt på regional byggeskik, og i de seneste årtier også industrialismens egne bygninger og boliger. Sandsynligvis som udtryk for en endnu hastigere samfundsudvikling er interessen vokset for at bevare sammenhængende hverdagsmiljøer, og nye kriterier for bevaringsværdighed er dukket op. Ud over mere traditionelle kriterier som historisk repræsentativitet optræder nye begreber som orienteringsværdi, informationsværdi, symbolværdi og fortælleværdi.

Byplanarkitekten Vibeke Fischer Thomsen opregner således følgende 5 værdier i Planstyrelsens Bevaringsplanlaegning fra 1979: 1. Historisk værdi: Alder, sjældenhed eller midtpunkt for historisk begivenhed. 2. Kulturhistorisk værdi: Det som "fortæller generelle træk om menneskenes vilkår”, f.eks. andelsbevægelsens mejerier. 3. Arkitekturhistorisk og kunsthistorisk værdi: Forekommer i bygninger fra alle perioder, f.eks. fra et middelalderhus i Kalundborg til Fåborg Museum fra 
1915. 4. Miljømæssige værdier: "Helheder med arkitektonisk sammenhæng, hvor det ikke er det enkelte hus, der har betydning, men den sammenhæng, hvori det indgår. Til sådanne helheder kan der knytte sig særlige irrationelle og vanskeligt definerbare værdier, ligesom der kan forekomme funktionelle og sociale kvaliteter." 5. Særlige værdier som affektionsværdi, herlighedsværdi og orienteringsværdi "eksempelvis et stort træ el. lign., der hjælper til at fastslå, hvor man befinder sig i byen". (1)

Denne udvikling kan følges både i diskussionen omkring fredning og bevaring, men også i de faktiske fredninger og ikke mindst i den omfattende dokumentation af bevaringsværdige kvarterer og helheder i form af den løbende udarbejdelse af kommuneatlas og i form af Kulturarvsstyrelsens temaunders $\phi$ gelser og temafredninger. Kulturarvsstyrelsen skønner, at der i Danmark findes i alt ca. 300.000 bevaringsværdige bygninger. Heraf er godt 9.000 fredede. Der er indtil nu udarbejdet 72 kommuneatlas, som registrerer fredede bygninger, bygningsværdier og bevaringsværdige miljøer i bred kulturhistorisk sammenhæng. Som eksempel på temaundersøgelser kan nævnes dokumentationen af folkeskoler 1850-1900 og landskoler 1900-1920, som gennemgår skolernes generelle udvikling som bygningstype, den skolepolitiske baggrund, mønstertegninger og samtidens opfattelse af, at en skole burde være "anselig og monumental". I samarbejde med lokale museer udvælges, unders $\emptyset$ ges og karakteriseres enkelte skolers historie og bevaringsværdi. Gennemgangen er ligesom de $\varnothing$ vrige temaunders $\varnothing$ gelser af f.eks. etageboliger, landbrugsbygninger, vandforsyningsanlæg, fyrtårne og missionshuse tilgængelig via Kulturarvsstyrelsens hjemmeside. (2)

I denne sammenhæng vil der blive fokuseret på kulturelle byggerier og specielt bibliotekerne.

\section{Bygningshistorisk overblik}

Kulturelle institutioner og byggerier kan afgrænses på flere måder, afhængigt af perioden og bredden af kulturbegrebet. De bredeste definitioner vil medtage alle former for forsamlingsbygninger, kirker, skoler og uddannelsesinstitutioner og derudover i det 20. århundrede massekulturens rum i form af underholdnings- og fritidsanlæg. De snævrere definitioner vil koncentrere sig om teatre, koncert- og operahuse, biografer, museer, udstillingsbygninger, arkiver og biblioteker.

Fælles for hele det kulturelle område er ekspansionen i forbindelse med fritidens udvikling i det 20. århundrede. Nogle af institutionerne opstår først eller får deres første selvstændige bygninger i dette århundrede som f.eks. folkebibliotekerne. Andre ændrer karakter som f.eks. teatre, der også får funktion som biografer. Der er både ligheder og afgørende og interessante forskelle mellem de enkelte bygningstypers historie, placering, udformning og indretning, som afspejler den kulturelle og kulturpolitiske udvikling. Generelt sker der hen mod årtusindskiftet en fusion i retning af "kulturhuse" med flere kulturelle funktioner. Det gælder både for store nationale institutioner som Statens Museum for Kunst og Det kongelige Bibliotek og for en lang række lokale institutioner og byggerier.

Teaterbygningernes historie kan føres tilbage til Operahuset i Fredericiagade fra 1701-03 og Nicolai Eigtveds bygning til Det kongelige Teater på Kongens Nytorv fra 1748, som efterfulgtes af Vilhelm Dahlerup og Ove Pedersens teaterbygning fra 1872-74. Med undtagelser som Helsing ør Teater fra 1817 fik de større provinsbyer deres egne teaterbygninger i de følgende årtier, typisk med markant beliggenhed i byrummet som en del af forrige århundredskiftes spektakulære borgerlige offentlighed, f.eks. Århus Teater af Hack Kampmann fra 1898-1900. (3) Desuden opførtes Tivoli 1843 og Casinoteatret i Amaliegade i 1845-47 som vintertivoli af H.C. Stilling. Efter 1. Verdenskrig fusionerede teatret med det nye medie filmen, og bygningsmæssigt opstod en ny type "folketeatre" med både scene og biograflærred. De nye biografteatre var mere nøgternt indrettet end de store borgerlige teatre, men ofte med elegant præg af Art Deco. Denne type kulminerede med opførelsen af Bellevue Teatret fra 1936-37, tegnet af Arne Jacobsen, ved Klampenborg nord for København. Dette teater var ligesom hele det rekreative anlæg omkring strandparken tæt forbundet med funktionalismens forestillinger om det moderne fritidsliv. Museernes, arkivernes og bibliotekernes bygningshistorie går tilbage til deres fælles nationale oprindelse i det kongelige kunstkammer, som hav- 
de til huse i det nuværende rigsarkiv på Slotsholmen. Herfra udspaltedes Nationalmuseet med egen bygning fra 1855 i Prinsens Palæ ved Frederiksholms Kanal. Statens Museum for Kunst fik en markant beliggenhed som en del af det $k \varnothing b e n-$ havnske voldgadekompleks med en nybygning fra 1896, tegnet af Vilhelm Dahlerup, og Det kongelige Bibliotek fik sin egen nybygning på Slotsholmen i 1906 med Hans J. Holm som arkitekt og Johannes Magdahl Nielsen som konduktør. Rigsarkivet ligger indtil videre fortsat i de oprindelige bygninger.

Af andre tidlige museumsbyggerier kan nævnes Thorvaldsens Museum fra 1848 af G.M. Bindesbøll, indretningen af Frederiksborg Slot som Nationalhistorisk Museum med den gamle brygger I. C. Jacobsen som mæcen og Ferdinand Meldahl som arkitekt og Ny Carlsberg Glyptoteket fra 1897 med Carl Jacobsen som mæcen og Vilhelm Dahlerup som arkitekt. Museerne fik ligesom teatrene en iøjnefaldende udbygning i de større provinsbyer i slutningen af det 19 . århundrede. Det samme gjaldt de store landsarkiver. I løbet af det 20. århundrede er der sket en alsidig udbygning af både kultur- og kunsthistoriske museer. Byggeriet har dog ikke været så omfattende og geografisk spredt som f.eks. biblioteksbyggeriet. Det har gennemgået en lignende udvikling fra tempelagtige bygninger med stram symmetrisk grundplan til stor bygningsmæssig variation, ofte med originalt arkitektonisk udtryk og fin beliggenhed. Museumsbyggeriet har aldrig nærmet sig samme karakter af standardisering som biblioteks- og skolebyggeriet. Ligesom for indholdets vedkommende har der i højere grad været tale om unika. (4)

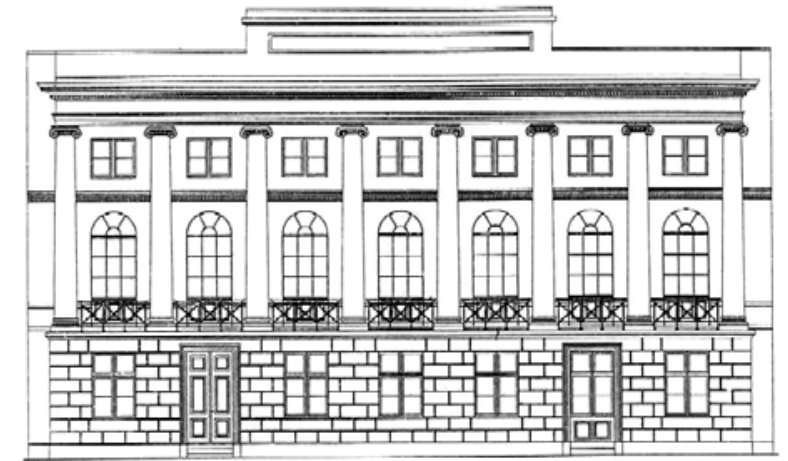

Det Classenske Bibliotek fra 1792, tegnet af Peter Hersleb Classen efter inspiration fra den franske oplysningsarkitektur. Kunstakademiets Bibliotek
Man kan diskutere, om den første selvstændige biblioteksbygning er bibliotekssalen i det nuværende rigsarkiv eller - oplysningshistorisk nok så interessant - Det Classenske Bibliotek i Amaliegade i København fra 1792, tegnet af Peter Hersleb Classen, der havde været på dannelsesrejse til Paris og utvivlsomt var inspireret af den franske revolutionsarkitektur som f.eks. E.-L. Boullées store biblioteksprojekt. (5) De store forskningsbiblioteker udbyggedes fra midten af det 19. århundrede som basilikaer med moderne jernkonstruktioner. Universitetsbiblioteket i Fiolstræde fra 1856-61 blev opført i murstensgotik af J.D. Herholdt og havde dekorationer af Georg Hilker. (6) Den moderne konstruktion var samtidig med Henri Labroustes store biblioteker i Paris, nemlig Bibliothèque Ste. Geneviève fra 1843-50 og Bibliothèque Nationale fra 1865-68. Tydeligt præg af Skønvirke havde både Statsbiblioteket i Århus fra 1902, tegnet af Hack Kampmann og med interiør af Karl Hansen-Reistrup (7), og Det kongelige Bibliotek af Holm fra 1906. (8) Der skete imidlertid ikke samme udbygning af bibliotekerne i større byer, som der gjorde for teatrenes, museernes og arkivernes vedkommende.

I 1876 var der 9 folkebogsamlinger i købstæderne, men flere hundrede på landet, ofte af mere midlertidig karakter. (9) Omkring forrige århundredskifte var forestillingen om folkebiblioteker, der var nyopført til formålet i egne bygninger, nærmest utopisk i ordets dobbelte betydning. I det første oversigtsværk Folkebogsamlinger. Deres Historie og Indretning fra år 1900 beskæftigede bibliotekspioneren Andreas Schack Steenberg sig kun med folkebiblioteksbyggeri som en kommende mulighed. Om bibliotekets bygning skrev Steenberg: "Noget af det første, et amerikansk eller engelsk Biblioteksudvalg har at gøre, er at tilvejebringe en Plan til en Biblioteksbygning. Herhjemme vil den Opgave at skaffe et passende Lokale til Bogsamlingen indtil videre måtte nøjes med en beskednere Løsning ... Men saa længe Folkebogsamlingerne spille saa beskeden en Rolle her i Landet som nu, maa de nøjes med beskedne Lokaler." (10) Herefter gennemgik Steenberg muligheder for lokalefællesskaber med f.eks. skoler og forsamlingshuse eller muligheden for at indrette sig i lejede lokaler. Det var vigtigt, at bibliotekets lokaler var centralt beliggende og helst $\mathrm{i}$ 
stueetagen, ligesom det gjaldt om at undgå flytninger. Biblioteksarbejdets pioneragtige karakter fremgik også af vandrebogsamlingernes primitive udstyr og indhold.

I bogens sidste afsnit "Vore Folkebogsamlingers Fremtid" vendte Steenberg dog tilbage til vigtigheden af særlige bygninger, gerne fælles med andre oplysende institutioner: "Der maa arbejdes hen til, at Folkebogsamlingerne faa et til deres Brug særligt indrettet Lokale. Kan man ikke opnaa at faa en særlig Bygning, hvad der naturligvis er det bedste, kan Bogsamlingen have Bygning fælles med andre Oplysningsinstitutioner, tekniske Skoler, Folkeskoler, Museer eller Foredragsforeninger ... Paa Landet vil der mange Steder kunne indrettes en Læsestue i Forsamlingsbygningen." (11) De mange lokalefællesskaber blev i høj grad en realitet i de kommende årtier. Forslaget om et lille bibliotek i tilknytning til en forsamlingsbygning pegede frem mod Stations-byudstillingens mønsterbibliotek i 1909.

I 1899 nybyggedes Køge Museum og Folkebibliotek i samme bygning. Ligesom forgængerne i k $\varnothing$ bstæderne og på landet blev det 20. århundredes første folkebiblioteker typisk oprettet af lokale biblioteksforeninger og drevet under vanskelige vilkår, ofte af lærere med stort personligt engagement. De mange foreninger fandt sammen i

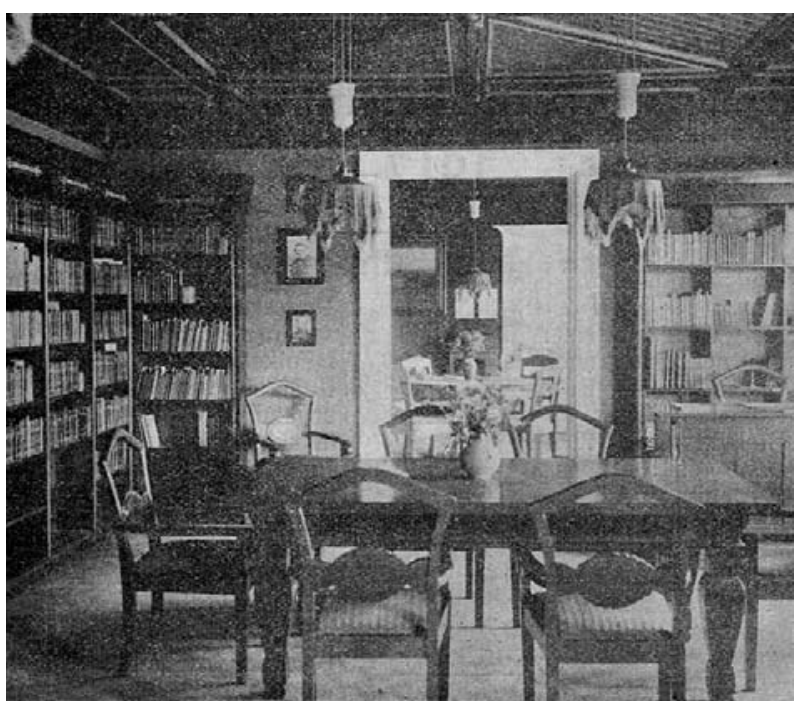

Hjemlig hygge i Vejen Bibliotek fra 1916. Efter Bogvennen, 1916. "bogsamlingsbevægelsen". Bibliotekerne var indrettet i forhåndenværende lokaler, ofte almindelige bylejligheder, og flyttede hyppigt. De havde stor betydning som "læsestuer" med sene åbningstider. Mennesker, der boede i små lejligheder med store familier - svarende til tidens boligforhold kunne derved få mulighed for at læse uforstyrret. Biblioteksrummet var delt op i "stuer", og indretning og møblering var dagligstueagtig med vægt på hjemlig hygge.

Som en "forædling" af denne bibliotekstype blev der oprettet et mønsterbibliotek i mønsterstationsbyen på Landsudstillingen i Århus i 1909. Udstillingen og biblioteket eksisterede dog kun et halvt år. På samme måde som stationsbyudstillingens arkitektur skulle være forbillede for kommende stationsbyer, skulle biblioteks- og forsamlingsbygningen med indretning og indhold i form af en mønsterbogsamling være forbillede for oprettelsen og udbygningen af folkebiblioteker på landet. En samtidig anmeldelse brugte begrebet "kulturcentrum" som karakteristik af det sammenbyggede bibliotek og forsamlingshus. Indretningen af biblioteket var næsten Carl Larssonsk med klare farver og rig anvendelse af træ. Statsbibliotekets leder Vilhelm Grundtvig understregede i en pjece om udstillingsbiblioteket, at det var vigtigt "med Billeder og anden (god) Kunst, Blomster o.lign. at skabe et hyggeligt og hjemligt Indtryk" ... "Et Bibliotek og en Læsesal er jo ikke blot et Rum for Bøger, men først og fremmest et Sted, hvor Mennesker skal søge Belæring, Underholdning eller Hvile efter endt Gerning." (12) Af stor betydning for bibliotekets rolle som forbillede var indretningen med åbne hylder, som i de følgende år slog igennem i danske folkebiblioteker, typisk i forbindelse med en panoptisk møblering med reolerne som "stråler" ud fra bibliotekarens skranke. Åbenheden lettede lånernes adgang til litteraturen og kunne ses som en demokratisering af biblioteksindretningen. Som Grundtvig skrev: "Enhver kan udsøge sig og udtage, hvad han ønsker." (13) Udstillingsbiblioteket inspirerede til oprettelsen og indretningen af biblioteket i Vejen i 1916, som i høj grad blev model for denne type af hjemlige "dagligstuebiblioteker" med praktisk og solid møblering i historiske stilarter eller Sk ønvirke. (14) 


\section{Folkebiblioteksbygninger ca. 1920-1950}

Den første selvstændige folkebiblioteksbygning blev nyopført i Køge i 1919, i øvrigt nu nedrevet. Næsten samtidig nyopførtes folkebiblioteket i Silkeborg, som stadig fungerer som bibliotek. Fra 1919 til 1929 nyopførtes yderligere i alt 15 folkebiblioteker, og fra 1930 til 1943, hvor biblioteksbyggeriet ophørte i en længere årrække på grund af krigen, nyopførtes yderligere 29. Dertil kom endnu flere ombygninger og nyindretninger. Denne udbygning af folkebibliotekerne i Danmark afspejlede både en social, kulturel og bibliotekspolitisk udvikling. Den var en del af mange provins- og stationsbyers modernisering, hvor også andelsmejerier, elværker, brandstationer, skoler, biografer og museer blev udbygget, ofte som små templer i en nøgtern klassicistisk stil. Ser man bort fra de få store nationale biblioteksbyggerier, er det interessant, at de første folkebiblioteksbygninger - i modsætning til teatre, museer og arkiver placerede sig i mindre provinsbyer og stationsbyer uden for de store byers etablerede borgerlige offentlighed.

Den $\varnothing$ gede fritid var et af mellemkrigstidens moderne fænomener, og kulturpolitisk var perioden præget af begreber som folkeoplysning og udviklingen af en moderne folkekultur. (15) I 1919 gennemførtes 8-timers arbejdsdagen, og i løbet af mellemkrigstiden skete der gradvist en udvidelse af fritiden, som fik stor betydning for hverdagslivet - fra friluftsliv og dyrkning af kolonihaver til læsning, oplysningsvirksomhed og andre kulturelle aktiviteter. I 1924 stiftedes både Arbejdernes Oplysningsforbund og Udvalget for Fritidssyssel, senere Dansk Folkeoplysnings Samråd, hvor en lang række af organisationer og bevægelser var repræsenteret. Folkebibliotekernes udbygning var en væsentlig side af mellemkrigstidens kulturpolitik. I bogen 10 Aars Arbejderoplysning, udgivet af AOF i 1934 som status over de første 10 års virksomhed, blev "det moderne Folkebibliotek" fremhævet som "Kulturcentrum" med tydelig forbindelse til vigtigheden af studiekredsarbejdet: "Alle vore Folkebiblioteker i Byerne burde gøres til et Kulturcentrum for Kommunen. Ved Siden af Udlaanslokaler og Læseværelser burde der være en Foredragssal og et eller flere Studiekredsværelser." (16) Netop indretningen af studiekredsværelser kom til at præge periodens folkebiblioteker.

I 1920 vedtoges Danmarks første bibliotekslov, som fik vidtrækkende betydning for folkebibliotekernes organisering og udvikling, herunder biblioteksbyggeriet. Samtidig oprettedes Statens Bibliotekstilsyn, som i de følgende årtier arbejdede for en modernisering og rationalisering af folkebibliotekerne, der også afspejledes i bygningernes udformning og indretning. Tilsynets første direktør blev Thomas Døssing, som personligt prægede periodens bibliotekspolitik, hvor folkeoplysning og rationalisering gik op i en højere enhed. Loven gav mulighed for en række statstilskud til folkebibliotekerne, såfremt de opfyldte lovens krav om bl.a. alsidig og oplysende sammensætning af bogbestanden. Til oprettelse eller nyordning af et bibliotek kunne der ydes 1/3 af det lokale tilskud.

En ny bibliotekstype udviklede sig i forlængelse af disse moderniseringsbestræbelser i løbet af tyverne og op gennem trediverne, nemlig det klassicistiske "videnstempel". Som eksempler kan nævnes Hjørring Bibliotek fra 1927, Århus Kommunebibliotek fra 1934, Frederiksberg Bibliotek fra 1935 og Thisted Bibliotek fra 1938. Også en lang række skoler, gymnasier og museer fra denne periode er bygget i samme stil. Idealtypisk for "videnstemplet" var en symmetrisk grundplan, formet som en "sommerfugl" med indgang og voksenudlån placeret i midteraksen som "krop" og voksenlæsesal og børnebibliotek på hver side som "vinger". Den klassicistiske monumentalitet understregedes yderligere af høje trapper op mod et fremhævet indgangsparti, ofte med lisener eller søjler. Symmetrien fortsattes ind $i$ forhallen og derfra videre ind i voksenudlånet til skranke eller bibliotekarbord. Herfra var der overblik over hele rummet. Kortkartoteket med registreringen af bibliotekets samlinger og typisk et ur for endevæggen var ligeledes placeret i midteraksen. Voksenudlånet kunne være et symmetrisk galleri med høje vinduer. Der var typisk højere til loftet i voksenudlånet end i bibliotekets $\varnothing$ vrige afdelinger og ofte ovenlys. Denne rumfordeling var praktisk af hensyn til anbringelsen af reoler og belysning, men samtidig understregede den biblioteksrummets ophøjethed og lysets mange betydninger. Både voksenudlån, læsesal og børnebibliotek var typisk nøgterne rum 


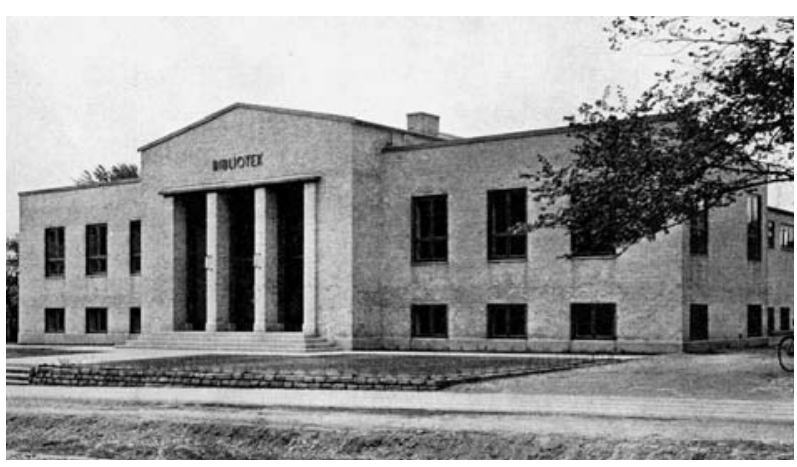

Thisted Bibliotek fra 1938 som "videnstempel" mellem klassicisme og modernisme, tegnet af Jens Foged. Efter Carl Jørgensen: Danske Biblioteksbygninger.

med enkel møblering uden dekoration. "Læsestuen" blev til "læsesalen". I de fleste biblioteker blev der indrettet studiekredslokaler og i de største også en foredragssal. På den måde orienterede bibliotekerne sig både i retning af arbejderoplysningens sociale indlæring, grundtvigianismens levende ord og dannelseskulturens klassiske forelæsningstradition. Klassicismens saglighed udvikledes i løbet af trediverne i modernistisk retning. Som eksempel kan nævnes Århus Kommunebibliotek med store glaspartier og indretning med stålrørsm øbler. Stockholms Stadsbibliotek af Gunnar Asplund fra 1928 er et eksempel af international betydning. (17)

I sin tale ved indvielsen af Århus Kommunebibliotek i 1934 understregede biblioteksdirekt $\varnothing r$ Thomas Døssing udviklingen fra almue- til folkebibliotek og tolkede bygningen som det moderne folkebibliotek for alle: 'Denne Bygning staar som Slutsten paa en Udvikling, som har sine Rødder over 100 Aar tilbage, og som er en direkte Følge af den demokratiske Folkerejsning i økonomisk og politisk Henseende ... Folkebiblioteker og Folkeskoler er nu Institutioner for alle Borgere. Den odiøse Klang er gaaet af Ordet Folk under disse Institutioners Vækst. Man har talt om Muligheden for en Arbejderkultur. Det skal jeg lade ligge, men en Folkekultur er det muligt at skabe ved at give alle Borgere Adgang til den højeste Oplysning. I denne Institution skal alle Mennesker mødes uden hensyn til politisk eller religiøs Anskuelse.” (18)

Oprettelsen af Statens Bibliotekstilsyn som central statslig instans og den aktive personkreds om-

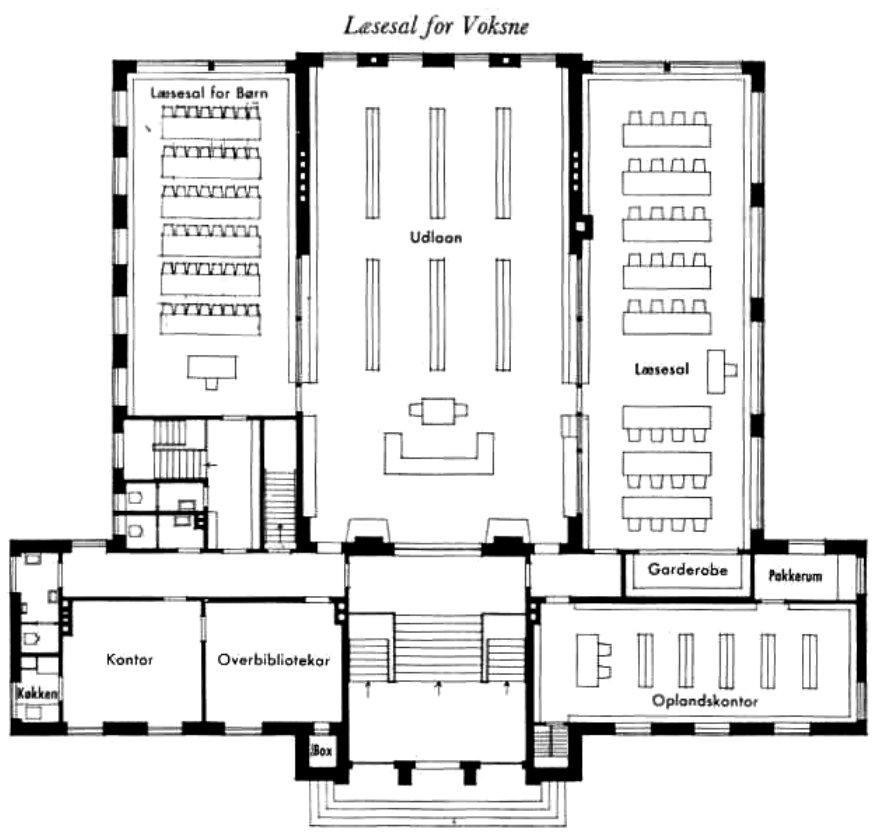

Grundplan fra Thisted Bibliotek. Efter Carl Jørgensen: Danske Biblioteksbygninger.

kring Thomas Døssing havde afgørende $\varnothing$ konomisk og ideologisk betydning. Der var i perioden flere modsætninger mellem dette moderne oplysningsmiljø på den ene side og den traditionelle bogsamlingsbevægelse på den anden side med repræsentanter for de mindre biblioteker, som $\emptyset$ nskede en mere decentral udvikling med større lokal indflydelse, bl.a. på bogvalget. På lokalt plan gik man f.eks. i højere grad ind for den mere traditionelle og underholdningsprægede litteratur i modsætning til den kritiske og eksperimenterende. Det er nærliggende at betragte de to nævnte bibliotekstyper, henholdsvis "dagligstuebiblioteket", som var indrettet hjemligt med solide møbler, potteplanter og billeder på væggene, og "videnstemplet", som var præget af den nye saglighed, som udtryk for disse forskellige bibliotekspolitiske retninger.

Det er dog også karakteristisk, at der i mellemkrigstiden ikke blev opført nogle egentlige modernistiske biblioteker i Danmark som f.eks. Alvar Aaltos bibliotek i Viipuri i Finland fra 1935. (19) Bibliotekstilsynets værdier og syn på biblioteksbyggeri kommer sandsynligvis til udtryk i følgende formuleringer af bibliotekskonsulent og senere biblioteksdirektør Robert L. Hansen i hans anmeldelse af Thisted Bibliotek i Bogens Verden. Det var tegnet af den lokale arkitekt Jens Foged og blev opført 1937-38. I sin indretning med sym- 


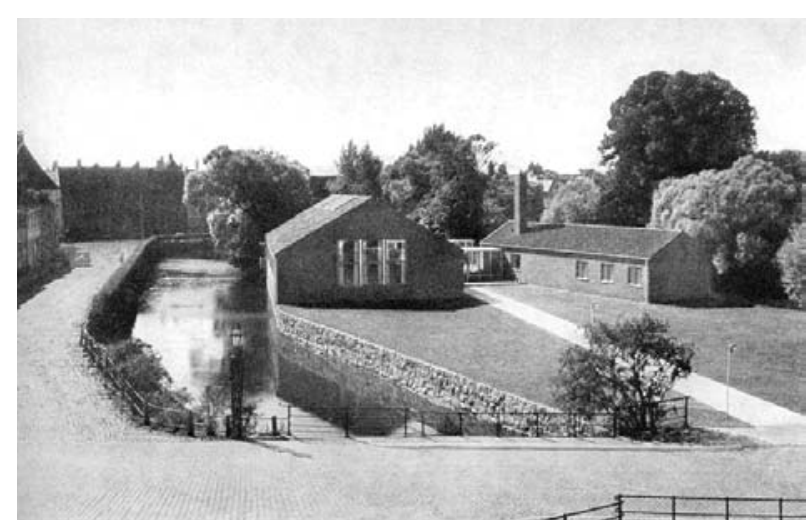

Med sin åbne og frie udformning reprosenterede Nyborg Bibliotek fra 1939 fornyelsen af mellemkrigstidens danske biblioteksbyggeri. Biblioteket var tegnet af Erik Mфller og Flemming Lassen med interiфr af Hans J. Wegner. Efter Arkitekten, 1940.

metrisk orden og højt til loftet var det et typisk "videnstempel" med kvaliteter, der stadig værdsættes af dets brugere. Robert L. Hansen var uhyre positiv over for den nye biblioteksbygning, som han betegnede som "et dejligt Bibliotek, ja, hvad det ydre angaar maaske det smukkeste af vore Folkebiblioteker." Han fremhævede det forsigtige arkitektoniske udtryk, dog i tidens ånd, men hvor man ligesom i Frederiksberg havde undgået den "yderliggående modernisme": "Bygningens ydre Stil, som for $\emptyset$ vrigt ogsaa dens Rumfordeling, kan minde noget om Frederiksberg, men er, maaske paa Grund af det lyse Byggemateriale, lettere i Linjerne, mere i Pagt med Tidens Aand, uden paa nogen Maade at virke udfordrende paa den jævne Beskuer". (20) I det indre var voksenudlånet udsmykket med syv store malerier af thylandske landskaber af Jens Søndergaard, skænket af Ny Carlsberg Fonden, som tog initiativ til flere større udsmykningsopgaver af periodens nye centralbiblioteker som f.eks. Valdemar Andersens og Niels Larsen Stevns' udsmykninger i Hjørring og Robert Storm Petersens dekorationer af børnebiblioteket i Esbjerg. (21) Robert L. Hansens kommentar viser sagligheden i Bibliotekstilsynets syn på biblioteksindretning, som svarer udmærket til periodens mange nøgne biblioteksvægge, næsten som et billedforbud, men også åbenheden over for den gode kunst, svarende til den gode litteratur, hvor Døssing ofte fremhævede Johannes V. Jensen: "... og hvad man end vil mene om Maleriers Betimelighed i Biblioteksrum, saa kan det ikke

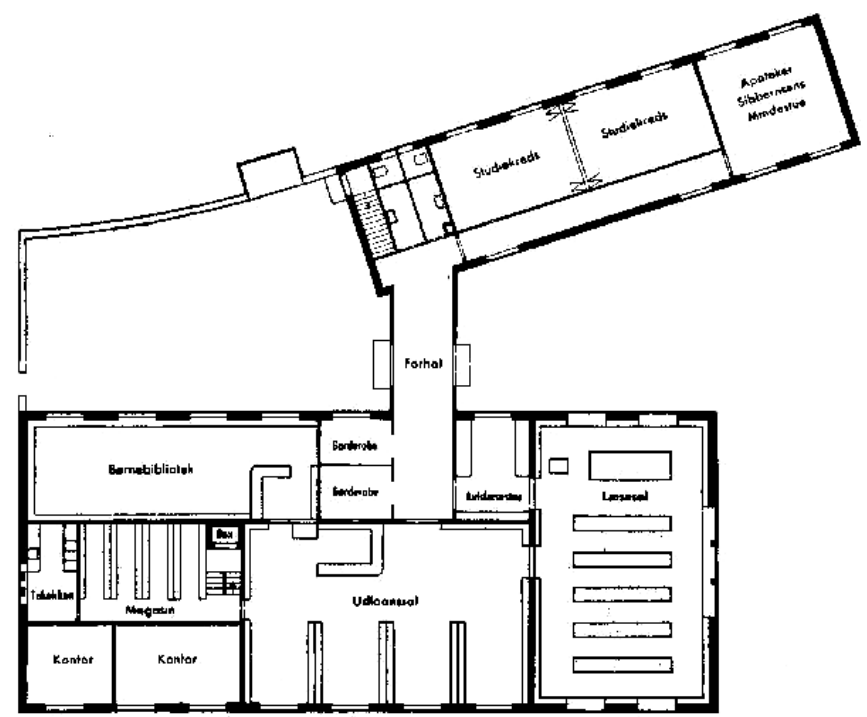

Grundplan fra Nyborg Bibliotek. Efter Carl Jørgensen: Danske Biblioteksbygninger.

nægtes, at de søndergaardske Billeder virker meget festlige med deres dybt rene grønne og blaa Farver, og de synes fortrinligt egnede til at virke formidlende mellem gammel og ny Kunst i det store Publikums Anskuelse." (22)

Mellemkrigstidens biblioteker havde dog talrige lokale variationer - både med hensyn til beliggenhed, stil og indretning. Som oftest blev bibliotekerne placeret efter den forhåndenværende bygnings eller byggegrunds princip. Både København, Odense og Ålborg klarede sig langt op gennem århundredet med genbrug af andre bygningstyper, især kirkelige. Vigtige undtagelser var Århus, Frederiksberg og Nyborg med markante placeringer i bybilledet. Den dominerende bibliotekstype var "videnstemplet" og den dominerende stil var det arkitektoniske kompromis mellem klassicisme og modernisme, men derudover var der flere eksempler på Bedre Byggeskik og andre historiske stilarter. De fleste biblioteker blev tegnet af lokale arkitekter, og der blev kun udskrevet ganske få arkitektkonkurrencer.

En undtagelse var på flere måder Nyborg Bibliotek, tegnet af Erik Møller og Flemming Lassen og opført 1938-39. Det var et af mellemkrigstidens sidste nybyggede biblioteker, og det kom på flere måder til at repræsentere en syntese af periodens kulturpolitik og biblioteksarkitektur. Som bygning bestod det af to lave rødstenslænger med asymmetrisk placering og store vinduespartier, forbundet af en lille overdækket glasgang, som med et enkelt trin op fungerede som indgang. Det 
var både traditionelt og moderne og blev et hovedværk inden for den "funktionelle tradition" i dansk arkitekturhistorie. Med sin åbne og im $\varnothing$ dekommende udformning og indretning brød det med tidens mere monumentale biblioteker. Den lette adgang og indretningen af studiekredslokalerne var en del af demokratiseringen af folkeoplysningen. Kulturpolitisk var det et fint udtryk for forestillingen om "Kulturen for Folket". Også bibliotekets indre var uhyre gennemtænkt og originalt. Interiøret blev udformet specielt til Nyborg Bibliotek af den senere internationalt kendte møbelarkitekt Hans J. Wegner. Væggene i udlån og læsesale var fra gulv til loft beklædt med lyse ahornspaneler. Tilsvarende var bibliotekets faste og løse inventar udført i ahorn. (23) Med Nyborg Bibliotek fik dansk biblioteksarkitektur som del af dansk kulturpolitik et nyt og selvstændigt udtryk, også i international sammenhæng. Et andet samtidigt eksempel med samme præg var Gladsaxe Bibliotek fra 1940, tegnet af Vilhelm Lauritzen.

\section{Folkebiblioteksbygninger ca. 1950-2000}

På grund af krigen kom der først fra midten af halvtredserne igen gang i biblioteksbyggeriet. I en status over det hidtidige byggeri understregede Robert L. Hansen i 1954 som biblioteksdirektør yderligere Nyborgs betydning. Han kritiserede tendensen til, at danske biblioteksbygninger havde for meget præg af "bureaukratiske ekspeditionslokaler". Nyborg var en undtagelse. (24)

Der er da heller ingen tvivl om, at biblioteksbyggeriet ændrede afgørende karakter i århundredets anden halvdel, både med hensyn til omfang, udformning og indretning. Fra 1950 til 1999 blev der nyopført ca. 120 folkebiblioteker, og der blev foretaget ca. 125 nyindretninger i andre lokaler eller større ombygninger. Den største byggeperiode var årene 1970-74 umiddelbart efter kommunalreformen. Her blev der bygget eller nyindrettet 40 folkebiblioteker. Mens nybyggeriet var st $\varnothing r s t ~ i$ periodens første årtier, har halvfemserne været præget af genbrug af eksisterende bygninger, ofte tidligere fabriksbygninger, butikslokaler m.m. Antallet af arkitektkonkurrencer er $\varnothing$ get med tilhørende muligheder for varierede og fornyende løsninger. Således har der i tidsskriftet Arkitekten været 12 omtaler af arkitektkonkurrencer siden
1950 i forhold til 1 omtale før (Nyborg). Bibliotekerne er blevet større, og de har generelt fået en mere central placering i bybilledet, ofte sammen med butikscentre.

Bibliotekspolitisk har perioden været præget af $\emptyset$ nsker om åbenhed og fleksibilitet, som bl.a. kom til udtryk i Bibliotekstilsynets Biblioteksbygning 1984 af Elisabeth Lylloff og Sven Plovgaard:

"Opløsningen af den oprindeligt strenge rumfordeling er fuldført, og vi ser en arkitektonisk mildning af den grundplansymmetri, der ellers længe hang efter 30'ernes omfattende fløjbyggeri ... Den nye holdning til biblioteksindretning giver en smidigere funktionsplan, leder til friere muligheder for materialeopstilling, møbelvalg og monteringsmønster. Institutionspræget er veget for individuelle, æstetisk betonede trivselsinteriører med mindre stram kanalisering af benyttelsesformerne." (25)

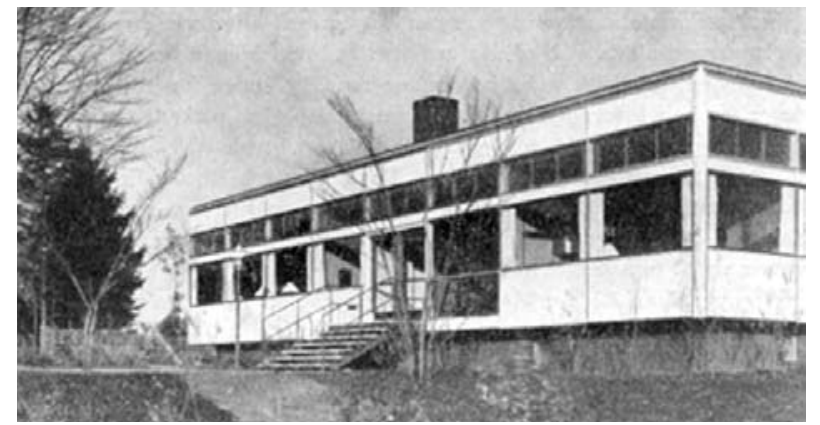

Hørsholm Bibliotek fra 1956 som det første kasseformede modernistiske étrumsbibliotek, tegnet af J. Juul-Mфller og Holger Nasted. I dag børneinstitution. Efter Bogens Verden, 1957.

Denne nye fleksibilitet gav større spillerum for skiftende arkitektoniske udtryk, således at biblioteksbyggeriet i højere grad har afspejlet generelle tendenser og retninger i arkitekturen. Tressernes nybyggeri var typisk præget af den sene modernismes minimalisme. Hørsholm fra 1956 var det første kasseformede, åbne og fleksible étrumsbibliotek, der senere efterfulgtes af f.eks. Værløse fra 1964, Lyngby fra 1968, Randers fra 1969 og Rødovre fra 1970. I Lyngby var børnebiblioteket indrettet med et kreativt legelandskab af Nanna Ditzel. Fra halvfjerdserne dukkede nye retninger op såsom inspirationen fra Louis Kahn med eksempler som Herlev fra 1971, Gladsaxe fra 1979 
med portal af Bjørn Nørgaard, Ålborg fra 1980 og Holstebro fra 1981. Gentofte Bibliotek fra 1985 lå i forlængelse af den hvide modernisme. Forskellige former for postmodernisme markerede sig med Horsens og Hørsholm fra 1988 og den dekonstruktive arkitektur med Hinnerup Bibliotek og Kulturhus fra 1993. Interessante eksempler på indretninger i tidligere industribygninger er $\mathrm{Ny}$ købing Mors og kvartershuset i Holmbladsgade i København, begge fra 2001. Med det vigende institutionspræg er også træk af "dagligstuebiblioteket "vendt tilbage i form bløde sofagrupper og grønne planter. Der er således stor variation i periodens biblioteksbyggeri. Et originalt arkitektonisk udtryk har givet flere biblioteker større synlighed i bybilledet. På den anden side har især tressernes minimalisme gjort bibliotekerne mindre synlige som bygningstype.

Fælles træk har været åbningen af bibliotekerne og biblioteksrummet, som startede med indførelsen af de åbne hylder i begyndelsen af århundredet. Denne åbning kan formidlingsmæssigt ses som udtryk for en generel kulturpolitisk holdning, som udvikles op gennem århundredet, og som bl.a. kommer til udtryk i Biblioteksloven fra 1964 og En kulturpolitisk redegørelse. Betcenkning $n r$. 517 fra 1969. Samtidig ligger den arkitektonisk i forlængelse af modernismens åbne rumopfattelse. Måske er der i de senere års byggeri en tendens til, at den større åbenhed på længere sigt vil "sløre" bibliotekernes grænser, både i forhold til andre kulturelle institutioner, der ligesom bibliotekerne indgår i de mange nye kulturhuse, og i forhold til den informationsteknologiske udviklings uafhængighed af fysiske rum.

Koncentrerer man sig om biblioteksbyggeriet som kulturarv, kan der anlægges både arkitekturhistoriske og bibliotekshistoriske vurderinger.

\section{Biblioteker som del af arkitekturhistorien: Den arkitektoniske kanon}

En entydig kanon med entydige kvalitetskriterier kan ikke fastlægges hverken inden for det arkitekturhistoriske eller bibliotekshistoriske område. Kilderne kan variere fra store oversigtsværker til mindre guides og ikke mindst den store mængde af anmeldelser og omtaler i fagtidsskrifter.
Bibliotekerne indgår i arkitekturhistorien med deres æstetiske og arkitektoniske kvaliteter, selv om den nyere arkitekturhistorie også inddrager sociale og ideologiske perspektiver. Det er nærliggende at tage udgangspunkt i Danmarks arkitektur, som er den seneste større samlede fremstilling af dansk arkitekturhistorie. Værket blev udgivet i seks bind i 1979-80 af forlaget Gyldendal med Hakon Lund som redaktør. Det kulturelle byggeri omtales i bindet Magtens bolig. I forordet til dette bind tages der udgangspunkt i magtbegrebets mange betydninger som både politisk- $\varnothing$ konomisk og kulturel magt: "Magtens arkitektoniske iklædning har antaget mange former fra stærkt fortællende, manende, maleriske til lavmælt indforståede ... Borgen, fæstningen og slottet var udtryk for den feudale magthavers potens, ligesom rådhuset, domhuset og arresten var det på det lokale plan ... Af mindst lige stor betydning for den politiske magt er at $\varnothing v e$ indflydelse på uddannelse, kunst og kultur, samt at give folket forlystelser. Skolen, teatret, sportspladsen, museet, biblioteket er nogle af de kategorier, hvor det arkitektoniske udtryk afspejler den gennem tiderne ændrede indstilling til folkeopdragelsen.” I bindets sidste kapitler med bl.a. overskriften Kundskab er magt sætter Lisbet Balslev Jørgensen disse kulturelle bygninger ind i en arkitekturhistorisk sammenhæng. Følgende biblioteker er medtaget, her i kronologisk orden: Universitetsbiblioteket over Trinitatis Kirke (Jörg Scheffel, 1637-56), Det kongelige Biblioteks første bygning på Slotsholmen, som er en del af det nuværende Rigsarkiv (Albert Mathiesen og Thomas Walgenstein, 166773), Det Classenske Bibliotek (Peter Hersleb Classen, 1792), Universitetsbiblioteket i Fiolstræde (J.D. Herholdt, 1857-61), Statsbibliotekets første bygning, som i dag rummer Erhvervsarkivet (Hack Kampmann, 1898-1902), Nyborg Bibliotek (Flemming Lassen og Erik Møller, 1938), Gladsaxe Bibliotek (Vilhelm Lauritzen, 1940) samt Rødovre Bibliotek (Arne Jacobsen, 1970). Desuden omtales Edvard Heibergs forslag til kulturcenter på Bispebjerg i København, som også indeholdt et bibliotek. (26)

En nyere kilde med mere aktuel orientering er basen Arkitekturbilleder, som er en dokumentation af dansk arkitektur i 20. og 21. århundrede. Udvalg og korte informative omtaler er redigeret 
af Kunstakademiets Arkitektskoles Bibliotek. I basen indgår følgende biblioteker, her i kronologisk orden: Statsbibliotekets første bygning (jvf. ovenfor), Nyborg Bibliotek (jvf. ovenfor), Rødovre Bibliotek (jvf. ovenfor), Birkerød Rådhus og Bibliotek (Ib og Jørgen Rasmussen, 1980), Gentofte Bibliotek (Hennings Larsens Tegnestue, 1985), Holstebro Rådhus og Bibliotek (Dall og Lindhardtsen, 1989), Musikbiblioteket i Odense (Kristian Isager, 1990), Universitetsbiblioteket i Fiolstræde (jvf. ovenfor samt restaurering og nyindretning ved David Bretton-Meyer, 1996-97), Det kongelige Biblioteks tilbygning "den sorte diamant" (Schmidt, Hammer og Lassen, 1999), Holmbladsgade Kvartercenter i København med bibliotek og mødelokaler (Dorte Mandrup, 2001) samt Haraldslund medborgerhus i Aalborg med pyramide, svømmehal, forsamlingslokaler og bibliotek (Jacob Blegvad; Christian Pedersen, 1970; 2002). Herudover er der omtaler af Statsbibliotekets nye bogtårn i forbindelse Århus Universitet (K. Fisker, C.F. Møller og P. Stegmann, 1933 og senere) og af Bibliotekarforbundets hus (Knud Munk, 1989-90). (27)

Også i andre arkitektoniske/arkitekturhistoriske oversigter er der stort sammenfald i udvalget af biblioteker frem til de seneste tiår. Bortset fra Danmarks Arkitektur, som ud over arkitekturen inddrager et kundskabshistorisk overblik, vægtes især æstetiske og materialemæssige kvaliteter.

\section{Arkitekturen som del af bibliotekshistorien: Den bibliotekariske kanon}

Det er påfaldende, at bibliotekernes bygninger ikke indtager en større plads i den generelle bibliotekshistorie. H. Hvenegaard Lassen giver i bogen De danske folkebibliotekers historie 1876-1940 fra 1962 en detaljeret og informativ beskrivelse af en central periode i folkebibliotekernes historie med hovedvægt på personer og institutioner. Dog får "1930'ernes store biblioteksbyggeri" et særligt kapitel. Her omtales især bygningernes tilblivelseshistorie og praktiske forhold ud fra en positiv pionervinkel. En enkelt biblioteksbygning fremhæves, nemlig Frederiksberg Bibliotek: "Dens hele plan og indretning var på mange punkter så epokegørende ny, at den utvivlsomt betegner højdepunktet i periodens biblioteksbyggeri” (28) Om
Nyborg Bibliotek hed det venligt imødekommende, men mere lakonisk: "Der er over bygningen noget let og lyst, som var noget nyt i dansk biblioteksbyggeri, og den vakte megen opmærksomhed og beundring i arkitektkredse." (29)

Leif Thorsens fremstilling De danske folkebiblioteker 1940-1983 fra 1992 er skrevet som en fortsættelse af Hvenegaard Lassens bog. Heri findes et ganske kort kapitel om "Bygninger og lokaler", hvor vægten er lagt på "folkebibliotekernes fysiske rammer i årene 1940-83 i almindelighed: byggerestriktioner, $\varnothing \mathrm{konomi}$, omfang, principper for lokalefordeling og lokaleindretning m.v." Thorsens holdning til byggeriet er overvejende kritisk: Selv om der ikke er tale om "paradebyggeri", er den afslappede indretning på den ene side blevet kedsommelig, pæn og forudsigelig, og på den anden side fik arkitekterne "i nogle tilfælde lov til at skabe bygninger for, syntes det, også at vække arkitektonisk opmærksomhed og til at udtænke arkitektoniske finurligheder i indretningen." Thorsen fremhæver Hørsholm Bibliotek af J. JuulMøller og Holger Næsted fra 1956 som det fleksible hus uden faste vægge med mulighed for skiftende opstillinger, Københavns Kommunes hovedbibliotek af O. Gundelach-Pedersen og Ebbe Andresen fra 1957 som det første gennemførte fagsalsbibliotek og Billund Bibliotek af Kuno og Ejner B. Meilby fra 1974 som del af et kulturcenter. (30) Inddragelsen af biblioteksbygninger i lokale bibliotekshistorier varierer i $\varnothing$ vrigt meget.

En fint indblik i mellemkrigstidens folkebiblioteksbyggeri giver Danske Biblioteksbygninger fra 1946. Bogen blev udarbejdet statusoversigt af arkitekten Carl Jørgensens med indledning af stadsbibliotekar Carl Thomsen. Den dækker et udvalg på 39 folkebiblioteksbygninger, som beskrives med vægt på deres praktiske indretning på grundlag af spørgeskemaer udsendt af Bibliotekstilsynet. Der er ikke foretaget "en rent arkitektonisk vurdering". Carl Thomsens afsnit vægter ligeledes praktiske aspekter som typer af biblioteksindretninger, placering af forskellige funktioner, studiekreds- og foredragslokaler, administrationslokaler, magasineringsbehov m.m.

En vigtig del af bogens dokumentation er de mange fotografier og tegninger af grundplaner. Carl 
Jørgensen havde selv tegnet 5 af de udvalgte biblioteker og samarbejdede med Biblioteks-tilsynet. Carl Thomsen var leder af Århus Kommunebibliotek og havde været med ved opførelsen af bibliotekerne i Esbjerg og Århus. Selv om omtalerne af de enkelte biblioteker er beskrivende og $n \varnothing \mathrm{g}$ terne med få forsigtige vurderinger, er det tydeligt, at nogle biblioteker er mere forbilledlige end andre: Om Frederiksberg Bibliotek, som får den længste omtale, står der: "Det er den største Folkebiblioteksbygning i Danmark og et ualmindeligt vellykket Resultat af en Arkitekts og en Biblioteksmands samlede Bestræbelser. Biblioteket har med god Grund, siden det blev taget i Brug, været besøgt af talrige Biblioteksfolk, som har studeret Bygningens klare Plandisposition og særdeles gennemtænkte Inventar." (31) Nyborg blev karakteriseret som "et charmerende Anlæg" med forbehold: "Nyborg Bibliotek kan ikke siges at være umiddelbart forbilledligt, thi dertil har det $\mathrm{i}$ for høj Grad skullet indpasses i netop disse Omgivelser, men inden for denne Begrænsning er Bygningen bemærkelsesværdig ved sine smukke og vel gennemtænkte Løsninger af mange Enkeltproblemer." (32)

Danske Biblioteksbygninger blev fulgt op af Folkebiblioteksbygningen af Sven Plovgaard fra 1967 (33) og Biblioteksbygning 1984 af Elisabeth Lylloff og Sven Plovgaard fra 1984. (34) Begge bøger anbefalede det fleksible étrumsbibliotek uden fast plan og faste vægge som et åbent rum med muligheder for skiftende funktioner og udvidelse. De administrativt orienterede anbefalinger ledsagedes af generaliserede planløsninger. Den åbne plan var et markant skift i forhold til mellemkrigstidens biblioteker. I Biblioteksbygning 1984 fremhævedes følgende planeksempler: Filialen Rødkærsbro i Bjerringbro kommune af P.E. Kappelgaard fra 1978, Rønde Bibliotek af Erik Hastrup Holm og Kjeld Kjeldsen fra 1981, Farum Bibliotek af FDB's arkitektkontor fra 1977 samt Kjær og Richters projekt til hovedbibliotek i Frederiksværk fra 1980.

Sammenligner man den arkitektoniske og den bibliotekariske kanon - med forbehold overfor kildernes forskellige karakter og perioder - er der tydelige forskelle mellem en mere faglig/æstetisk og en mere faglig/praktisk vurdering. Forskellen træder bl.a. frem i de forskellige vurderinger af Frederiksberg og Nyborg Biblioteker. Begge typer af vurderinger er væsentlige - også i kulturarvssammenhæng.

\section{Behov for fredning, bevaring og dokumentation}

Spørgsmålet om fredning og bevaring rejser flere problemer. For det første er nogle bygningstyper sværere at bevare end andre, især hvis bevaringen også skal omfatte bygningens indre. Nogle institutioners og bygningers funktioner har ændret sig mere end andres. F.eks. har sygehusenes patientbehandling ændret sig mere end kirkernes gudstjeneste. Skolernes undervisningsformer ændrer sig mere end det traditionelle teaters indretning og brug. Også bibliotekernes materialer, formidlingsformer og brugere har ændret sig - med konsekvenser for biblioteksbygninger, som ud fra forskellige begrundelser kunne være interessante at bevare som en del af kulturarven. I hvor høj grad skal bibliotekets formidling tilpasse sig de eksisterende rammer - og hvor meget kan man nyindrette, uden at væsentlige værdier går tabt? Skal biblioteket som yderste konsekvens flytte til andre lokaler, og hvad skal den bevarede bygning i givet fald anvendes til? Er det tilstrækkeligt at bevare bygningens ydre skal, eller er det lige så vigtigt at bevare dens indre?

For det andet er der den store gruppe af mere anonyme, men ikke mindre tidstypiske biblioteker, som har været brugt af masser af lånere, og som har lige så stor erindrings- og fortælleværdi i lokalsamfundet som de kanoniserede. Hvis man med den amerikanske arkitekturteoretiker Robert Venturis begreber generelt karakteriserer de biblioteker, som har været nævnt, som "heroic and original", er der stadig langt størstedelen af biblioteksbygningerne tilbage som "ugly and ordinary". Læseoplevelsen kan have været lige så stor og kulturformidlingen lige så vigtig i den ombyggede villa, den beskedne folkebiblioteksbungalow eller biblioteket i bylejligheden.

I forlængelse heraf ligger for det tredje problemstillinger omkring fredningens begrundelse, nemlig forholdet mellem en på den ene side mere æstetisk/bygningshistorisk begrundet fredning, hvor det væsentlige er hensynet til bygningens 
udseende, fysiske rammer og interiør/udsmykning af høj kunstnerisk eller håndværksmæssig kvalitet, og på den anden side en mere kultur/bibliotekshistorisk begrundet fredning, hvor det væsentlige er bygningens praktiske udformning og rumlige indretning som historisk forbillede for andre biblioteker eller som tidstypisk udtryk, herunder materialernes opstilling og tilgængelighed for publikum og en eventuel udsmyknings kulturpolitiske karakter.

Det er derfor interessant at undersøge, hvor mange og hvilke biblioteksbygninger der er fundet værdige til fredning samt fredningens karakter og eventuelle begrundelse: Det Classenske Bibliotek, Universitetsbiblioteket i Fiolstræde og Nyborg Bibliotek er er de eneste fungerende biblioteker, der er fredet - Nyborg Bibliotek som det eneste med samme biblioteksfunktion, nemlig som kommunalt folkebibliotek siden 1938. Fredningerne er fra henholdsvis 1918, 1932 og1986. Kunstakademiets Bibliotek er fredet som en del af Charlottenborg med en tidlig fredning fra 1918, og Rådhusbiblioteket i København er fredet som en del af Københavns Rådhus med en fredning fra 1981. Fredninger af bygninger, der tidligere har fungeret som biblioteker, omfatter: Det kongelige Biblioteks første bygning, som nu er Rigsarkiv, og som blev fredet i 1950, Wegeners Gård, som var et privat bibliotek fra 1857, tegnet af Carl Rasmussen og fredet 1981, Statsbibliotekets første bygning, som blev fredet i 1988, herunder "læsesalens nagelfaste inventar, inkl. lysekronerne" og endelig Hjørring Biblioteks tidligere bygning ligeledes med en fredning fra 1988. Derudover er Dragør Bibliotek indrettet $\mathrm{i}$ en fredet bygning, ligesom Kunstakademiets Arkitektskoles Bibliotek på fornem vis er nyindrettet $\mathrm{i}$ en tidligere klejnsmedje i det bevaringsværdige miljø på Holmen i København. (35)

Bortset fra at disse 9 fredninger er yderst rimelige, kan man ikke sige, at de udgør nogen stor del af de i alt ca. 9000 fredede bygninger i Danmark, ej heller at de udgør noget repræsentativt udsnit af dansk biblioteksbyggeri, især ikke i nyere tid, endsige i forhold til bibliotekstyper eller gruppen af "kanoniserede" biblioteker. Fredningerne og de få angivne begrundelser peger i retning af hensynet til bygningernes arkitektoniske og kunstneriske kvaliteter. På linie med Kulturarvsstyrelsens фvrige tematiske gennemgange og fredninger af bygningstyper kunne man derfor forestille sig et fredningsinitiativ rettet mod udvalgte biblioteker med en bredere dækning end den nuværende og om muligt rettet mod biblioteker, hvor der i forvejen i lokalsamfundet og blandt brugere og personale vil være forståelse for en fredning. F.eks. bør et af de allerførste byggerier og et af mellemkrigstidens "videnstempler" fredes/sikres bevaring med centrale dele af indretning og udsmykning, ligesom flere biblioteker med markante udsmykninger kunne komme på tale.

Af lige så stor betydning som egentlige fredninger er imidlertid opmærksomheden omkring de bygningsmæssige og indretningsmæssige værdier. En sådan opmærksomhed hos befolkning, personale, arkitekter og $\varnothing$ vrige instanser kan både føre til bevaring af væsentlige elementer eller genanvendelse/nyopstillling af historisk inventar i forbindelse med større ombygninger eller flytninger og under alle omstændigheder bør den føre til bedre dokumentation af hidtidige forhold. Man kan kun beklage den tilsyneladende forsvinden af mange specialtegnede interiører af høj håndværksmæssig kvalitet, af de tidlige stålrørsmøbler og især den manglende dokumentation af en lang række biblioteksinteriører og formidlingssituationer.

På Danmarks Biblioteksskole findes en lille samling af historisk biblioteksudstyr, hvoraf der i øjeblikket er udstillet en enkelt biblioteksskranke, en skrivepult, et bogskab fra et sognebibliotek med indhold samt eksempler på biblioteksteknisk udstyr. En sådan samling kunne videreudvikles i retning af rekonstruktionen af små interiører, hvor bibliotekernes historie, men også læsningens historie i bredere sociologisk og kulturhistorisk sammenhæng, kunne illustreres gennem indretning af nicher med læsem øblering og litteratur fra udvalgte miljøer og perioder. Det er ligeledes muligt at gøre tekst- og billeddokumentation elektronisk tilgængelig.

Den aktuelle informationsteknologiske udvikling er en stor udfordring for bibliotekerne ved årtusindskiftet. Den nødvendigg ør nye funktioner og fleksible indretningsmuligheder. Som afslutning 
skal der ikke peges på færdige løsninger, men på vigtigheden af en historisk dimension: på behov for identitet, historisk bevidsthed og i forlængelse heraf dokumentation, bevaring og fredning, i det omfang det er muligt. Kravet om fleksibilitet vil sandsynligvis i endnu højere grad ramme "indholdet" end den bygningsmæssige "skal". Bibliotekerne bør udvise øget opmærksomhed over for bygninger, historisk inventar og dokumentation af hidtidige forhold i forbindelse med større nyindretninger eller flytninger - som en del af kulturarven.

\section{Noter}

1. Peter Dragsbo og Nina Fabricius: De kulturhistoriske bevaringsinteresser i: Kulturbevaring og dagligt liv. Red. af Peter Dragsbo og Nina Fabricius, København, Statens Museumsnævn, 1987, s.21-24.

2. http://www.kuas.dk/bygningsfredning/ index.htm

3. Lise Funder: Dansk Teaterbyggeri 1870-1910, København, Gad, 1986.

4. Temanummer af Kunst og Museum om Kunstmuseer, arkitekter og arkitektur, Kunst og Museum, 1983.

5. Anne Grønli: Oplysningstidens bibliotek i: Bibliotek och arkitektur. Red. af Magdalena Gram, Stockholm, Arkitekturmuseet, 2002, s. $18-31$

6. Knud Millech: J.D. Herholdt og Universitetsbiblioteket i Fiolstrade, København, Erik Paludan, 1961.

7. Emanuel Sejr: Statsbiblioteket. Forhistorie og tilblivelse, Århus, Statsbiblioteket, 1963.

8. Det kongelige Bibliotek - et hus på Slotsholmen, København, Det kongelige Bibliotek, 1993.

9. H. Hvenegaard Lassen: De danske folkebibliotekers historie 1876-1940, København, Dansk Bibliografisk Kontor, 1962, s. 17.
10. Andreas Schack Steenberg: Folkebogsamlinger, Aarhus og København, Jydsk Forlags-Forretning, 1900, s. 94.

11. Samme, s. 167.

12. Vilh. Grundtvig: Stationsbyens Folkebibliotek, Aarhus, 1909, s. 8.

13. Samme, s. 3.

14. Nan Dahlkild: Biblioteket på Landsudstillingen $i$ Arrhus 1909 i: Bibliotek och arkitektur. Red. af Magdalena Gram, Stockholm, Arkitekturmuseet, 2002, s. 42-49.

15. Nan Dahlkild: Kampen om den frie tid - fritiden som moderne problem i mellemkrigstiden i: Bogens Verden, 1987:6, s. 357-361.

16. 10 Aars Arbejderoplysning, København, Arbejdernes Oplysningsforbund, 1934, s. 103.

17. Vilma H. Fröberg: Tystnaden och ljuset, Stockholm, Carlssons, 1998, s.199-203.

18. Aarhus Folkebibliotek i: Bogens Verden, 1934, s. 278 .

19. Michael Spens: Viipuri Library, London, Academy Edtions, 1994.

20. Robert L. Hansen: Det nye Bibliotek i Thisted i: Bogens Verden, 1938, s. 167.

21. Poul Vad: Billedet, vaggen og rummet, København, Gyldendal, 1968, s. 20 ff.

22. Robert L. Hansen: Det nye Bibliotek $i$ Thisted i: Bogens Verden, 1938, s. 168.

23. Erik Møller og Flemming Lassen: Folkebiblioteket $i$ Nyborg i: Arkitekten, Maaneds-hefte, 1940, Kjeld Vindum: Den store moderator i: UNDR, Nyt Nordisk Forum, 56, Nils-Ole Lund: Beskedenhed er en pryd i: Arrestforvarerens drenge - og andre historier om Nyborg Bibliotek. Red. af Jan Witzel, Nyborg, Nyborg Bibliotek, 2002, s. 67-72 samt Nan Dahlkild: Arkitektur som kulturpolitik i: samme, s. 51-66. 
24. Biblioteksdirektørens Foredrag i: Bogens Verden, 1954, s. 456.

25. Elisabeth Lylloff og Sven Plovgaard: Biblioteksbygning 1984, Ballerup, Biblioteks-centralens Forlag, 1984, s. 24.

26. Danmarks arkitektur. Red. af Hakon Lund. København, Gyldendal, 1979-80. Magtens bolig, s.116 ff.

27. http://217.157.129.230/billedbasen/index.php September 2003.

28. H. Hvenegaard Lassen: De danske folkebibliotekers historie 1876-1940, København, Dansk Bibliografisk Kontor, 1962, s. 317-18.

29. Samme, s. 321.

30. Leif Thorsen: Danske folkebiblioteker 19401983, København, Dansk Bibliotekscenter, 1992, s.161-165.

31. Carl Jørgensen: Danske Biblioteksbygninger, København, Folkebibliotekernes Bibliografiske Kontor, 1946, s. 120-130.

32. Samme, s. 95-98.

33. Sven Plovgaard: Folkebiblioteksbygningen, København, Bibliotekscentralen,1967.

34. Elisabeth Lylloff og Sven Plovgaard: Biblioteksbygning 1984, Ballerup, Biblioteks-centralens Forlag, 1984.

35.

http://www.kuas.dk/bygningsfredning/index.ht m Herudover tak for hjælp og særlige oplysninger til Elisabeth von Buchwald og andre medarbejdere i Kulturarvsstyrelsen.

\section{Litteratur}

Arrestforvarerens drenge - og andre historier om Nyborg Bibliotek. Red. af Jan Witzel, Nyborg, Nyborg Bibliotek, 2002.
Bibliotek och arkitektur. Red. af Magdalena Gram, Stockholm, Arkitekturmuseet, 2002.

Danmarks arkitektur. Red. af Hakon Lund. København, Gyldendal, 1979-80.

Fröberg, Vilma H.: Tystnaden och ljuset, Stockholm, Carlssons, 1998.

Funder, Lise: Dansk Teaterbyggeri 1870-1910, København, Gad, 1986.

Hvenegaard Lassen, H.: De danske folkebibliotekers historie 1876-1940, København, Dansk Bibliografisk Kontor, 1962.

Jørgensen, Carl: Danske Biblioteksbygninger, København, Folkebibliotekernes Bibliografiske Kontor, 1946.

Det kongelige Bibliotek - et hus på Slotsholmen, København, Det kongelige Bibliotek, 1993.

Kulturbevaring og dagligt liv. Red. af Peter Dragsbo og Nina Fabricius, København, Statens Museumsnævn,1987.

Kunstmuseer, arkitekter og arkitektur, Kunst og Museum, 1983.

Lylloff, Elisabeth og Sven Plovgaard: Biblioteksbygning 1984, Ballerup, Bibliotekscentralens Forlag, 1984.

Millech, Knud: J.D. Herholdt og Universitetsbiblioteket $i$ Fiolstraede, København, Erik Paludan, 1961.

Plovgaard, Sven: Folkebiblioteksbygningen, København, Bibliotekscentralen,1967.

Sejr, Emanuel: Statsbiblioteket. Forhistorie og tilblivelse, Århus, Statsbiblioteket, 1963.

Spens, Michael: Viipuri Library, London, Academy Edtions, 1994.

Thorsen, Leif: Danske folkebiblioteker 1940-1983, København, Dansk Bibliotekscenter, 1992. 